Bangl. J. Vet. Med. (2007). 5 (1 \& 2): 25-32

\title{
CHARACTERIZATION OF ESCHERICHIA COLI ISOLATED FROM SAMPLES OF DIFFERENT BIOLOGICAL AND ENVIRONMENTAL SOURCES
}

\author{
M. A. Zinnah ${ }^{1}$, M. R. Bari ${ }^{2}$, M. T. Islam ${ }^{1 \& 3}$, M. T. $\operatorname{Hossain}^{1}$, M. T. Rahman ${ }^{1}$, M. H. Haque ${ }^{1}$, S. A. M. Babu ${ }^{4}$, \\ R. P. Ruma ${ }^{1}$ and M. A. Islam ${ }^{1} *$ \\ ${ }^{1}$ Department of Microbiology and Hygiene, Faculty of Veterinary Science, Bangladesh Agricultural University, \\ Mymensignh-2202, Bangladesh \\ *Corresponding author’s e-mail address: alim_bau@yahoo.co.in
}

\begin{abstract}
Escherichia coli from 10 different biological and environmental sources were isolated and characterized in the Department of Microbiology and Hygiene, Bangladesh Agricultural University, Mymensingh during the period from January to May 2007. A total of 100 samples, 10 from each of human feces and urine, rectal swab of cattle, sheep and goat, cloacal swab of chicken, duck and pigeon, drain sewage and soil were collected aseptically and subjected to primary isolation by propagating in nutrient broth followed by culture on different agar media. Gram's staining and hanging drop techniques were also performed. Biochemical properties of the isolates were studied and reaction in TSI agar slant was also observed. Pathogenicity of 10 representative E. coli isolates, one from each source were determined by lethality assay in 12 day-old embryonated eggs, in day-old chicks and in day-old suckling mice models. E. coli was isolated successfully from all the samples. All the E. coli isolates were found to produce bright pink colonies on MacConkey agar, yellowish green colonies surrounded by an intense yellow green zone on BG agar and characteristic metallic sheen colonies on the EMB agar. In case of $E$. coli isolated from cattle, slight variation in colony character on EMB agar was observed showing greenish red colonies with faint metallic sheen. In Gram's staining technique, all the isolates were pink coloured, small rod shaped Gram negative bacilli and in the hanging drop technique they were motile. Reactions in TSI agar slant revealed yellow slant and butt with gas but no hydrogen sulphide production. Almost all the E. coli isolates fermented dextrose, maltose, lactose, sucrose and mannitol with the production of both acid and gas except $E$. coli isolated from drain sewage which did not ferment maltose and isolates from pigeon showed less production of acid and gas during sucrose fermentation. The results of Catalase, MR and indole test of the $E$. coli isolates were positive but V-P test was negative. In the embryo lethality assay, $E$. coli isolates from chicken, pigeon, duck, human urine, cattle, sheep and goats were virulent causing $33.33-100 \%$ death of the embryo except isolates from human faeces and drain sewage which were moderately virulent and that from soil which was avirulent. E. coli isolate of chicken origin found to be more virulent which caused 100\% death of the embryos. Most of the embryos died between day-1 and day-2 PI. Chick lethality assay indicated that all the $E$. coli isolates were virulent as the mortality rate was more than $50 \%$. In mice lethality assay, all the E. coli isolates were in the killer group causing cent percent death of mice within 10 to $42 \mathrm{~h}$ following inoculation. Among these three lethality assay models, avian embryo lethality assay was found to be most suitable to discriminate between virulent and avirulent isolates compared to day-old chick lethality assay and day-old suckling mice lethality assay where inconsistent results were observed. In conclusion, our result showed that $E$. coli isolated from different biological and environmental sources were found to be varied in virulence and avian embryo lethality assay was assumed to be the best model for discriminating virulent and avirulent E. coli.
\end{abstract}

Key words: Escherichia coli, pathogenicity, human, cattle, poultry, soil

\section{INTRODUCTION}

Escherichia coli is considered as the normal bowel flora of different species of mammals and birds but some strains of $E$. coli possess pathogenic character due to the acquisition of virulent factors. Microbial characteristics associated with virulent $E$. coli include production of enterotoxin, verotoxin, colicins and siderophores, type-1 pili and motility, resistance to the lytic action of the host complement and antibiotics (Dho and Lafont, 1984; Chulasiri and Suthienkul, 1989).

Present address: ${ }^{2}$ School of Agriculture and Rural Development, Bangladesh Open University, Gazipur-1705, ${ }^{3}$ Department of Medicine, Faculty of Veterinary Science, Bangladesh Agricultural University, Mymensignh-2202, Bangladesh, ${ }^{4}$ Poultry Production Research Division, BLRI, Savar, Dhaka. 
The enteric E. coli are divided into six groups on the basis of their virulence properties such as enterotoxigenic (ETEC, causative agent of diarrhea in humans, pigs, sheeps, goats, cattle, dogs and horses), enteropathogenic (EPEC, causative agent of diarrhoea in humans, rabbits, dogs, cats and horses), enteroinvasive (EIEC, found only in humans), verotoxigenic (VTEC, found in pigs, cattle, dogs and cats), enterohaemorrhagic (EHEC, found in human, cattle, and goats) and enteroaggregative E. coli (EAggEC, found only in human). E. coli is a major pathogen of commercial poultry causing colibacillosis with manifestations such as airsacculitis, pericarditis, septicemia, and death of the birds (about 28\% death in Sonali birds) (Biswas et al., 2006). Enterotoxigenic E. coli (ETEC) is a major pathogen of animals, being responsible for diarrhea in calves resulting significant financial losses. Debnath et al. (1990) claimed $28 \%$ of the total death in calves occurred in first month of life and $50 \%$ of death during first week due to $E$. coli infection. It also causes on-farm contamination of different animal species (Fairbrother and Nadeau, 2006). ETEC is the most common cause of food and water-borne human diarrhea worldwide. In developing countries, the incidence of enteric diseases due to ETEC is estimated about 650 million cases per year, resulting in 800,000 deaths, primarily in children of below five years old (Turner et al., 2006).

E. coli is an important zoonotic pathogen. E. coli O157:H7 was first recognized in 1982 as a human pathogen and cattle have been identified as a major source of E. coli O157:H7 infection of human but it is not pathogenic in cattle and present in the feces of healthy cattle (Elder et al., 2000). Moreover, E. coli isolation reveals fecal contamination in the combined-sewer outflows (Perez Guzzi et al., 2000). So, it is necessary to emphasize the detection of $E$. coli from sewage water that may cause severe illness in animals and birds as well as in human being. Therefore, isolation and characterization of $E$. coli prevailing in different biological and environmental sources and study on their pathogenicity are important to reveal the distribution of different strains of $E$. coli organism in different animals, birds and the human being as well. Hence, the present research was undertaken to isolate and characterize $E$. coli from 10 different biological and environmental sources.

\section{MATERIALS AND METHODS}

\section{Collection of samples}

Urine samples were collected from adult men and women of the staff quarter and Health Care Centre of Bangladesh Agricultural University (BAU), Mymensingh with a history of chronic urinary tract infection; faecal samples from the students of different halls of BAU, Mymensingh, with a history of acute diarrhea; cloacal swabs from the cloacae of chickens and ducks of the Poultry Farm, BAU, Mymensingh; rectal swabs from cattle, sheep and goat of the Dairy Farm, Sheep and Goat Farm and the Veterinary Clinic, BAU, Mymensingh; drain sewage from the drain of the Dairy Farm, Poultry Farm, different halls and staff quarter areas, BAU, Mymensingh and soil samples were collected from different locations of the BAU campus, Mymensingh. A number of 10 of each type of samples from each source were collected aseptically over a period of January to February 2007.

\section{Isolation and identification of E. coli}

\section{Culture of the samples}

All the samples were cultured primarily in nutrient broth at $37^{\circ} \mathrm{C}$ for $18-24 \mathrm{~h}$, then subcultured onto the MacConkey, brilliant green and EMB agar by streak plate method (Cheesbrough, 1985) to observe the colony morphology (shape, size, surface texture, edge and elevation, colour, opacity etc). The organisms showing characteristic colony morphology of E. coli was repeatedly subcultured onto EMB agar until the pure culture with homogenous colonies were obtained.

\section{Microscopic study by Gram's staining method}

Gram's staining was performed as per procedures described by Merchant and Packer (1969) to determine the size, shape and arrangement of bacteria. The organisms revealed gram negative, pink colored with rod shaped appearance and arranged in single or in pair were suspected as E. coli. 


\section{Motility test by hanging drop technique}

The motility test was performed by hanging drop technique as described by Cowan (1985) to differentiate the motile bacteria from the non-motile one. Hanging drop slide was prepared by broth culture and examined under 100X power objective. The motile organisms were suspected as E. coli.

\section{Reaction of the organism in TSI agar slant}

The test organisms were cultured into TSI agar slant by stab or streak method. Yellow slant, yellow butt, presence of gas bubbles and absence of black precipitate in the butt (due to the production of $\mathrm{H}_{2} \mathrm{~S}$ ) indicative of E. coli (Carter, 1986).

\section{Carbohydrate fermentation test}

The test was performed by inoculating $0.2 \mathrm{ml}$ of nutrient broth culture of the isolated organisms into the tubes containing five basic sugars such as dextrose, maltose, lactose, sucrose and mannitol and incubated for $24 \mathrm{~h}$ at $37^{\circ} \mathrm{C}$. Acid production was indicated by the color change from red to yellow and gas production was noted by the accumulation of gas bubbles in the inverted Durham's tube (Cheesbrough, 1985).

\section{Catalase test}

A volume of $3 \mathrm{ml}$ of catalase reagent $\left(3 \% \mathrm{H}_{2} \mathrm{O}_{2}\right)$ was taken in a test tube. Single colony from the pure culture of $E$. coli was taken with a glass rod and merged in the reagent and observed for bubble formation which indicated positive test. Absence of bubble formation indicated negative result (Cheesbrough, 1985).

\section{Methyl Red test}

Single colony from the pure culture of the test organism was inoculated in $5 \mathrm{ml}$ of sterile MR-VP broth. After 5 days incubation at $37^{\circ} \mathrm{C}, 5$ drops of methyl red solution was added and observed for color formation. Development of red or yellow color indicated positive or negative result, respectively (Cheesbrough, 1985).

\section{Voges -Proskauer (V-P) test}

The test organisms were grown in $3 \mathrm{ml}$ of sterile MR-VP broth at $37^{\circ} \mathrm{C}$ for $48 \mathrm{~h}$ and then $0.6 \mathrm{ml}$ of $5 \%$ alphanapthol and $0.2 \mathrm{ml}$ of $40 \%$ potassium hydroxide containing $0.3 \%$ creatine was added per $\mathrm{ml}$ of broth culture. Following well shaking, the broth was allowed to stand for 5-10 minutes to observe the color formation. Development of pink-red color indicated positive result (Cheesbrough, 1985).

\section{Indole test}

The test organisms were cultured in $3 \mathrm{ml}$ of peptone water containing tryptophan at $37^{\circ} \mathrm{C}$ for $48 \mathrm{~h}$. One ml of diethyl ether was added, shaked well and allowed to stand until the ether rises to the top. Then 0.5 ml Kovac's reagent was gently run down the side of the test tube to form a ring in between the medium and the ether. Development of brilliant red colored ring indicated positive test (Cheesbrough, 1985).

\section{Determination of pathogenicity of $E$. coli isolates in different experimental model}

\section{Chicken embryo lethality assay}

Embryo lethality was performed as stated by Wooley et al. (2000) and Nolan et al. (1992). Ten representative E. coli isolates, one from each source were used for this assay. Overnight broth cultures of each isolate were washed twice in phosphate buffered saline (PBS), resuspended and diluted in PBS and inoculated into the allantoic cavity of six 12 day-old embryonated chicken eggs for each test isolate at a volume of $0.1 \mathrm{ml}$ (200 to 300 colony forming units). Six eggs were also inoculated by a known virulent and an avirulent E. coli isolates, respectively obtained from the repository of the Department of Microbiology and Hygiene, Bangladesh Agricultural University, Mymensingh. Six PBS inoculated and uninoculated control embryonated eggs were also included in this study. Eggs were candled daily and deaths were recorded until the embryos were 18 days of age. Allantoic fluid (AF), liver, spleen, heart and brain of the embryos were collected immediately after death for reisolation of the infecting $E$. coli. Isolates causing embryo death of $>29 \%, 10 \%-29 \%$ and $<10 \%$ were considered as, virulent, moderately virulent and avirulent isolates, respectively. 


\section{Chick lethality assay}

The virulence of 10 representative $E$. coli isolates, one from each source, was also determined by performing day-old chick lethality assay. Separate groups of day-old chicks, 3 chicks for each inoculum, were inoculated orally by bacteria, crude toxin and both bacteria and crude toxin respectively. Crude toxin was prepared by filtering (millipore filter) the supernatant from the centrifuged overnight broth culture. A volume of $0.8 \mathrm{ml}$ of washed (with PBS) bacterial cells (approx.1.9 x 10 $\mathrm{CFU}$ ), equal volume of crude toxin and same volume of bacteria with crude toxin (approx. $4.8 \times 10^{8} \mathrm{CFU}$ ) of each test isolate of E. coli was inoculated orally in separate groups of day-old chicks (3 chicks for each inoculum and 9 for each isolate) and observed frequently for mortality up to 7 days. Similarly, a known virulent and avirulent $E$. coli were inoculated in day-old chicks while 3 day-old chicks were kept uninoculated control. E. coli isolates that killed $>50 \%, 10 \%-50 \%$ and $0-10 \%$ of chicks were considered as virulent, moderately virulent and avirulent, respectively (Ngeleka et al., 2002). On necropsy of dead chicks intestinal contents were taken for reisolation of the infecting E. coli.

\section{Mice lethality assay}

Likewise chick lethality assay, mice lethality assay of the $E$. coli isolates were performed in day-old suckling mice. Here, $50 \mu \mathrm{l}$ of washed bacterial cell (approx. $1.2 \times 10^{8} \mathrm{CFU}$ ), equal volume of crude toxin and same volume of bacteria with crude toxin (approx. $3 \times 10^{7} \mathrm{CFU}$ ) of each representative isolate of E. coli were inoculated orally in separate groups of day-old suckling mice and observed frequently for mortality for 5 days. Isolates that killed more than $50 \%$ of mice were considered under killer group, and isolates that killed $0-50 \%$ of mice were considered as non-killers (Johnson et al., 2006). On necropsy of the dead mice, intestinal contents were taken for reisolation of the infecting E. coli.

\section{Statistical analysis}

The data of the death rate in different experimental models caused by the different isolates of E. coli was analyzed by ANOVA for significant difference and pair-wise mean comparison was performed by Duncun's Multiple Range Test using statistical package MSTAT-C.

\section{RESULTS AND DISCUSSION}

All the E. coli isolates were able to produce bright pink colonies on MacConkey agar, yellowish green colonies surrounded by an intense yellow green zone on BG agar and characteristic metallic sheen colonies on the EMB agar. In case of E. coli isolated from cattle, slight variation in colony character on EMB agar was observed showing greenish red colonies with faint metallic sheen. Differences in colony morphology manifested by the isolates may be due to loosing or acquiring some properties by the transfer of host or choice of host tissue as observed by Dean (1990) and Dubreuil et al. (1991). In Gram's staining, the morphology of the isolated bacteria exhibited pink coloured, small rod shaped, Gram negative bacilli and in the hanging drop technique all the isolates revealed motility as observed by several authors (Buxton and Fraser, 1977; Freeman, 1985; Jones, 1987). Reactions in TSI agar slant revealed yellow slant and butt with gas but no production of hydrogen sulphide gas was observed which supports the finding of Buxton and Fraser (1977).

In the present study almost all the isolates of E. coli fermented dextrose, maltose, lactose, sucrose and mannitol with the production of both acid and gas but $E$. coli isolated from drain sewage did not ferment maltose and isolate from pigeon showed less production of acid and gas during sucrose fermentation. Ali et al. (1998) also studied the biochemical characteristics of the different strains of $E$. coli isolated from different sources. They reported a little or no difference in these biochemical characters and stated that such similarity among the isolates might be due to presence of some common genetic materials. The results of Catalase, MR and indole test of the E. coli isolates were positive but V-P test was negative which are in agreement with the reports of Buxton and Fraser (1977) and Honda et al. (1982).

\section{Chicken embryo lethality assay}

Results of the present study revealed that isolate of $E$. coli from chicken origin and control $\mathrm{V}_{1}$ (known virulent) caused $100 \%$ death of the embryos followed by $66.66 \%$ by the isolate from pigeon and $50 \%$ by the isolates of duck and human urine (Table 1). Isolates from cattle, sheep and goat were responsible for 33.33\% death of the embryos while $E$. coli isolates from human feces and drain sewage caused $16.66 \%$ death. No mortality of the embryos was recorded by the isolates from the soil and known control avirulent $E$. coli $\left(\mathrm{V}_{2}\right)$. The higher rate of embryo mortality caused by E. coli isolate of chicken origin might be due to host specificity. 
The death rates of embryo ranged from $100 \%$ to $0 \%$ and most of the embryonic death occurred between day-1 and day-2 PI in this study which are in agreement with the findings of Nolan et al. (1992), Wooley et al. (2000), Gibbs et al. (2003) and Montgomery et al. (2005) who recorded 100\% to 0\% embryo mortality following inoculation with $E$. coli isolates of avian origin and most of the death of embryos in day-2 PI. They also noticed that the avirulent isolates had an embryo death rate of $<10 \%$, moderately virulent had a $10 \%-29 \%$ death rate, and virulent isolates had a death rate of $>29 \%$. According to them, in the present study $E$. coli isolates from chicken, pigeon, duck, human urine, cattle, sheep and goat were virulent though the embryo mortality caused by these isolates significantly $(\mathrm{p}<0.01)$ varied $(33.33-100 \%)$. Isolates from human faeces and drain sewage were moderately virulent while $E$. coli isolated from soil was avirulent one.

Marked skin hemorrhages throughout the body of the dead embryos on day-1 PI and hemorrhages along with edema throughout the body on day-2 PI and onward were observed following inoculation with virulent isolates. No such lesions were found in control embryos. Hemorrhages and edema were also present in embryos inoculated with moderately virulent isolates. Marked change in the color of allantoic fluid was also observed. No lesions were observed in PBS-inoculated and uninoculaed control group over the 6-days observation.

Table 1. Chicken embryo lethality assay following inoculation of different E. coli isolates through allantoic cavity route

\begin{tabular}{|c|c|c|c|c|c|c|c|c|c|}
\hline \multirow{2}{*}{$\begin{array}{l}\text { Sources of E. coli } \\
\text { isolates }\end{array}$} & \multirow{2}{*}{$\begin{array}{l}\text { Inoculum } \\
\text { (CFU/0.1ml) }\end{array}$} & \multicolumn{6}{|c|}{ Deaths days of post inoculation } & \multirow{2}{*}{ Total $^{\mathrm{A}}$} & \multirow[t]{2}{*}{ \% Dead } \\
\hline & & 1 & 2 & 3 & 4 & 5 & 6 & & \\
\hline Human urine & 258 & 1 & 1 & - & - & 1 & - & $3 / 6$ & $50.00^{\mathrm{C}}$ \\
\hline Human feces & 224 & 1 & - & - & - & - & - & $1 / 6$ & $16.66^{\mathrm{e}}$ \\
\hline Cattle & 257 & 2 & - & - & - & - & - & $2 / 6$ & $33.33^{\mathrm{d}}$ \\
\hline Sheep & 264 & - & 1 & 1 & - & - & - & $2 / 6$ & $33.33^{\mathrm{d}}$ \\
\hline Goat & 282 & 1 & - & - & 1 & - & - & $2 / 6$ & $33.33^{\mathrm{d}}$ \\
\hline Chicken & 205 & 3 & 2 & - & - & 1 & - & $6 / 6$ & $100.0^{\mathrm{a}}$ \\
\hline Duck & 291 & 1 & - & - & - & 1 & 1 & $3 / 6$ & $50.00^{c}$ \\
\hline Pigeon & 230 & 1 & 1 & 2 & - & - & - & $4 / 6$ & $66.66^{\mathrm{b}}$ \\
\hline Drain sewage & 228 & - & 1 & - & - & - & - & $1 / 6$ & $16.66^{\mathrm{e}}$ \\
\hline Soil & 271 & - & - & - & - & - & - & $0 / 6$ & 0.00 \\
\hline $\mathrm{V}_{1}$ & 248 & 2 & 2 & 1 & 1 & - & - & $6 / 6$ & $100.0^{\mathrm{a}}$ \\
\hline $\mathrm{V}_{2}$ & 237 & - & - & - & - & - & - & $0 / 6$ & 0.00 \\
\hline PBS control & - & - & - & - & - & - & - & $0 / 6$ & 0.00 \\
\hline $\begin{array}{l}\text { Uninoculated } \\
\text { control }\end{array}$ & - & - & - & - & - & - & - & $0 / 6$ & 0.00 \\
\hline \multicolumn{9}{|c|}{ Level of significance } & $* *$ \\
\hline
\end{tabular}

${ }^{\mathrm{A}}$ Total no. of dead embryos/total no. inoculated, - indicates no death, $\mathrm{V}_{1}=$ Known virulent $E$. coli isolate, $\mathrm{V}_{2}=$ Known avirulent $E$. coli isolate, ${ }^{* *}$ Significant at $\mathrm{p}<0.01$, Values with different superscripts within the same column differ significantly $(\mathrm{p}<0.01)$.

\section{Day-old chick lethality assay}

Almost all the $E$. coli isolates caused cent per cent mortality of day-old chicks except isolates from human feces and drain sewage which caused $66.66 \%$ mortality (Table 2). Death of the chicks occurred within 12 to $145 \mathrm{~h}$ following inoculation of bacteria. The degree of virulence was determined as described in the materials and methods section. The result indicated that all the $E$. coli isolated from different sources were virulent as they caused more than $50 \%$ mortality of the day-old chicks following inoculation. No significant $(\mathrm{p}>0.05)$ variation in mortality of chicks was observed between most of the $E$. coli isolates except isolates of human feces and drain sewage origin. The present findings contradict with the findings of Amara et al. (1996) and Ngleka et al. (2002) who recorded a variable degree of virulence ranging from high to moderate. This may be due to difference in route of inoculation and bacterial load in the inoculum. When the day-old chicks were inoculated with crude toxin alone and in combination with bacteria, inconsistent mortality of chicks was observed which could not be compared due to unavailability of the literatures. 
Table 2. Pathogenicity of different isolates of $E$. coli in day-old chicks following oral inoculation

\begin{tabular}{|c|c|c|c|c|c|c|}
\hline \multirow{3}{*}{$\begin{array}{l}\text { Sources of } \\
\text { E. coli isolates }\end{array}$} & \multicolumn{6}{|c|}{ Death of day-old chicks $(n=3)$} \\
\hline & \multicolumn{2}{|c|}{ Bacteria } & \multicolumn{2}{|c|}{ Crude toxin } & \multicolumn{2}{|c|}{ Bacteria with crude toxin } \\
\hline & No. (\%) & MDT (h) & No. (\%) & MDT (h) & No. (\%) & MDT (h) \\
\hline Human urine & $3(100)^{\mathrm{a}}$ & 12 & $3(100)^{a}$ & 12 & $0(0.0)$ & - \\
\hline Human feces & $2(66.66)^{b}$ & 70 & $0(0.0)$ & - & $0(0.0)$ & - \\
\hline Cattle & $3(100)^{a}$ & 97 & $3(100)^{\mathrm{a}}$ & 20 & $0(0.0)$ & - \\
\hline Sheep & $3(100)^{\mathrm{a}}$ & 24 & $3(100)^{\mathrm{a}}$ & 91 & $0(0.0)$ & - \\
\hline Goat & $3(100)^{a}$ & 110 & $3(100)^{a}$ & 64 & $0(0.0)$ & - \\
\hline Chicken & $3(100)^{\mathrm{a}}$ & 145 & $3(100)^{\mathrm{a}}$ & 39 & $3(100)^{\mathrm{a}}$ & 137 \\
\hline Duck & $3(100)^{a}$ & 46 & $3(100)^{a}$ & 74 & $3(100)^{\mathrm{a}}$ & 70 \\
\hline Pigeon & $3(100)^{\mathrm{a}}$ & 44 & $0(0.0)$ & - & $0(0.0)$ & - \\
\hline Drain sewage & $2(66.66)^{b}$ & 61 & $0(0.0)$ & - & $0(0.0)$ & - \\
\hline Soil & $0(0.0)$ & - & $2(66.66)^{b}$ & 37 & $0(0.0)$ & - \\
\hline $\mathrm{V}_{1}$ & $3(100)^{\mathrm{a}}$ & 95 & $3(100)^{a}$ & 42 & $3(100)^{\mathrm{a}}$ & 110 \\
\hline $\mathrm{V}_{2}$ & $0(0.0)$ & - & $1(33.33)^{\mathrm{C}}$ & 85 & $0(0.0)$ & - \\
\hline Uninoculated control & $0(0.0)$ & - & $0(0.0)$ & - & $0(0.0)$ & - \\
\hline Level of significance & $* *$ & & $* *$ & & $* *$ & \\
\hline
\end{tabular}

$\mathrm{n}=$ Number of day-old chicks used for each inoculum, MDT = Mean death time, $\mathrm{V}_{1}=$ Known virulent $E$. coli isolate, $\mathrm{V}_{2}=$ Known avirulent $E$. coli isolate, ${ }^{* *}$ Significant at $\mathrm{p}<0.01$, Values with different superscripts within the same column differ significantly ( $\mathrm{p}<0.01)$.

Day-old suckling mice lethality assay

All the mice inoculated with different $E$. coli isolates died showing marked diarrhea within 10 to $42 \mathrm{~h}$ following inoculation (Table 3). Only known avirulent E. coli isolate caused 33.33\% mortality of the mice.

Table 3. Pathogenicity of different isolates of E. coli in day-old suckling mice following oral inoculation

\begin{tabular}{|c|c|c|c|c|c|c|}
\hline \multirow{3}{*}{$\begin{array}{l}\text { Sources of } \\
\text { E. coli isolates }\end{array}$} & \multicolumn{6}{|c|}{ Death of day-old suckling mice $(\mathrm{n}=3)$} \\
\hline & \multicolumn{2}{|c|}{ Bacteria } & \multicolumn{2}{|c|}{ Crude toxin } & \multicolumn{2}{|c|}{ Bacteria with crude toxin } \\
\hline & No. (\%) & MDT (h) & No. (\%) & MDT (h) & No. (\%) & MDT (h) \\
\hline Human urine & $3(100)^{a}$ & 11 & $3(100)^{a}$ & 15 & $3(100)^{a}$ & 12 \\
\hline Human feces & $3(100)^{a}$ & 11 & $3(100)^{a}$ & 10 & $3(100)^{\mathrm{a}}$ & 12 \\
\hline Cattle & $3(100)^{a}$ & 18 & $3(100)^{\mathrm{a}}$ & 17 & $3(100)^{\mathrm{a}}$ & 35 \\
\hline Sheep & $3(100)^{\mathrm{a}}$ & 13 & $3(100)^{\mathrm{a}}$ & 36 & $3(100)^{\mathrm{a}}$ & 34 \\
\hline Goat & $3(100)^{\mathrm{a}}$ & 10 & $3(100)^{a}$ & 09 & $3(100)^{\mathrm{a}}$ & 11 \\
\hline Chicken & $3(100)^{\mathrm{a}}$ & 10 & $3(100)^{a}$ & 09 & $3(100)^{\mathrm{a}}$ & 11 \\
\hline Duck & $3(100)^{\mathrm{a}}$ & 33 & $3(100)^{a}$ & 18 & $3(100)^{\mathrm{a}}$ & 19 \\
\hline Pigeon & $3(100)^{a}$ & 36 & $3(100)^{a}$ & 33 & $3(100)^{\mathrm{a}}$ & 34 \\
\hline Drain sewage & $3(100)^{a}$ & 12 & $3(100)^{a}$ & 23 & $3(100)^{a}$ & 14 \\
\hline Soil & $3(100)^{\mathrm{a}}$ & 15 & $3(100)^{a}$ & 39 & $3(100)^{\mathrm{a}}$ & 44 \\
\hline $\mathrm{V}_{1}$ & $3(100)^{\mathrm{a}}$ & 10 & $3(100)^{a}$ & 13 & $3(100)^{a}$ & 14 \\
\hline $\mathrm{V}_{2}$ & $1(33.33)^{b}$ & 42 & $1(33.33)^{b}$ & 55 & $1(33.33)^{b}$ & 67 \\
\hline Uninoculated control & $0(0.0)$ & - & $0(0.0)$ & - & $0(0.0)$ & - \\
\hline Level of significance & $* *$ & & $* *$ & & $* *$ & \\
\hline
\end{tabular}

$\mathrm{n}=$ Number of day-old chicks used for each inoculum, MDT = Mean death time, $\mathrm{V}_{1}=$ Known virulent $E$. coli isolate, $\mathrm{V}_{2}=$ Known avirulent $E$. coli isolate, ${ }^{* *}$ Significant at $\mathrm{p}<0.01$, Values with different superscripts within the same column differ significantly $(\mathrm{p}<0.01)$. 
All the isolates of $E$. coli here in this study were in the killer group as they killed more than $50 \%$ of mice which are discordant with the findings of Johnson et al. (2006) who recorded $41 \%$ killers of the 90 E. coli strains. They performed the mice lethality assay of $E$. coli strains in 6-8 weeks old female Swiss mice which were subjected to $200 \mu \mathrm{l}$ subcutaneous inoculation in the abdomen, whereas in the present study the day-old mice were inoculated by $50 \mu \mathrm{l}$ of inoculum through oral route. Same death pattern of mice was observed when crude toxins alone and in combination with bacteria were used as inocula.

Among the three lethality assay models, day-old chick lethality assay and day-old suckling mice lethality assay revealed inconsistent results compared to the results of avian embryo lethality assay. Furthermore, avian embryo lethality assay was able to discriminate between virulent and avirulent $E$. coli isolates as to the previous reports (Ngleka et al., 2002; Gibbs et al., 2004; Montgomery et al., 2005; Jhonson et al., 2006). Gibbs et al. (2003) also suggested the possibility that the embryo lethality assay may prove to be the one test needed to determine if an avian E. coli isolate is virulent.

In conclusion, our result showed that $E$. coli isolated from different biological and environmental sources were found to be varied in virulence from high to avirulent and avian embryo lethality assay was assumed to be the best model for discriminating virulent and avirulent $E$. coli.

\section{REFERENCES}

1. Ali MY, Rahman MT, Islam MA, Choudhury KA and Rahman MA (1998). Characteristics of E. coli isolates of human and animal origin. Progressive Agriculture 9 (1-2): 221-224.

2. Amara A, Had SE, Jirrari T and Bouzoubaa K (1996). Lethality, hemagglutination and adhesion of Escherichia coli strains (serotype 01) isolated in Morocco from chickens with colibacillosis. Avian Diseases 40 (3): 540-545.

3. Biswas PK, Uddin GM, Barua H, Roy K, Biswas D, Ahad A and Debnath NC (2006). Causes of loss of Sonali chickens on smallholder households in Bangladesh. Preventive Veterinary Medicine 76 (3-4): 185-195.

4. Buxton A and Fraser G (1977). Animal Microbiology. Vol. 1. Escherichia coli, Blackwell Scientific Publications, Oxford, London, Edinburg, Melbourne. pp: 92-102.

5. $\quad$ Carter GR (1986). Essentials of Veterinary Bacteriology and Mycology. $3^{\text {rd }}$ edn., pp. 312-330.

6. Cheesbrough M (1985). Medical laboratory manual for tropical countries. Vol. II. Microbiology. pp. 400-480.

7. Chulasiri M and Suthienkul O (1989). Antimicrobial resistance of Escherichia coli isolated from chickens. Veterinary Microbiology 21: 189-194.

8. Cowan ST (1985). Biochemical behavior of E. coli. Journal of General Microbiology 8: 391.

9. Dean FA (1990). Comparison of receptors of 987p pili of enterotoxigenic E. coli in the small intestines of neonatal and older pigs. Infection and Immunity 58: 4030- 4035.

10. Debnath NC, Sil BK, Selim SA, Prodhan MAM and Howlader MR (1990). A respective study of calf morbidity and mortality in small holder traditional farms in Bangladesh. Preventive Veterinary Medicine 9: 1-7.

11. Dho M and Lafont JP (1984). Adhesive properties and iron uptake ability of Escharichia coli lethal and nonlethal for chicks. Avian Diseases 28: 1016-1025.

12. Dubreuil JD, Fairbrither JM, Lallier R and Lariviere S (1991). Production and purification of heat stable enterotoxin-b from a porcine E. coli strain. Infection and Immunity 59: 198-203.

13. Elder RO, Keen JF and Siragusa GR. (2000). Correlation of enterohemorrhagic Escherichia coli O157 prevalence in feces, hides, and carcasses of beef cattle during processing. Proceedings of the National Academy of Sciences 97: 29993003.

14. Fairbrother JM and Nadeau E (2006). Escherichia coli: On-farm contamination of animals. Review of Science and Technology 25 (2): 555-569.

15. Freeman BA (1985). Burrows Textbook of Microbiology. $22^{\text {th }}$ edn., In: W. B. Saunders Company, Philadelphia, London, Toronto, Mexico city, Rio de Janerio, Sydney, Tokyo, pp. 464- 475.

16. Gibbs PS, Maurer JJ, Nolan LK and Wooley RE (2003). Prediction of chicken embryo lethality with the avian Escherichia coli traits complement resistance, colicin $\mathrm{V}$ production, and presence of the increased serum survival gene cluster (iss). Avian Diseases 47 (2): 370-379.

17. Honda T, Arita M, Taklea Y and Miwatani T (1982). Further evaluation of the Biken test (Modified Eleck test) for detection of enterotoxigenic E. coli producing heat labile enterotoxin and application of the test for sampling of heat stable enterotoxin. Journal of Clinical Microbiology 16 (1): 60-62.

18. Johnson JR, Clermont O, Menard M, Kuskowski MA, Picard B and Denamur E (2006). Experimental mouse lethality of Escherichia coli isolates, in relation to accessory traits, phylogenetic group, and ecological source. Journal of Infectious Diseases 194 (8): 1141-1150.

19. Jones TO (1987). Intramammary antibiotic preparations and cephalosporin resistance in Salmonella typhimurium 204c. Veterinary Record 120: 399-400. 
20. Merchant IA and Packer RA (1969). Veterinary Bacteriology and Virology. $7^{\text {th }}$ edn., The Iowa State University Press, Ames, Iowa, USA. pp. 211-305.

21. Montgomery RD, Jones LS, Boyle CR, Luo Y and Boyle JA (2005). The embryo lethality of Escherichia coli isolates and its relationship to various in vitro attributes. Avian Diseases 49 (1): 63-69.

22. Ngeleka M, Brereton L, Brown G and Fairbrother JM (2002). Pathotypes of avian Escherichia coli as related to tsh-, pap-, pil-, and iuc-DNA sequences, and antibiotic sensitivity of isolates from internal tissues and the cloacae of broilers. Avian Diseases 46 (1): 143-152.

23. Nolan LK, Wooley RE, Brown J, Spears KR, Dickerson HW and Dekich M (1992). Comparison of a complement resistance test, a chicken embryo lethality test, and the chicken lethality test for determining virulence of avian Escherichia coli. Avian Diseases 36 (2): 395-397.

24. Perez Guzzi JI, Folabella A, Miliwebsky E, Rivas M, Fernandez Pascua C, Gomez D, Zamora A, Zotta C and Cordoba M (2000). Isolation of Escherichia coli O157:H7 in storm drains in the city of Mar del Plata with bacterial contamination of fecal origin. Revista Argentina de Microbiologia 32 (3): 161-164.

25. Turner SM, Scott-Tucker A, Cooper LM and Henderson IR (2006). Weapons of mass destruction: virulence factors of the global killer enterotoxigenic Escherichia coli. FEMS Microbiology Letters 263 (1): 10-20.

26. Wooley RE, Gibbs PS, Brown TP and Maurer JJ (2000). Chicken embryo lethality assay for determining the virulence of avian Escherichia coli isolates. Avian Diseases 44 (2): 318-324. 